\title{
Liver dysfunction in patients with IBD under immunosuppressive treatment: do we need to fear?
}

\author{
Laurent Beaugerie, ${ }^{1}$ Alexander L Gerbes ${ }^{2}$
}

There is an ineluctable trend in the treatment of inflammatory bowel disease (IBD) towards an extensive use of immunosuppressive drugs. These agents are prescribed earlier in the disease, ${ }^{1}$ in an increased proportion of patients (reaching one-third in some European countries ${ }^{2}$ ) and for prolonged periods since their impact on the disease course is unfortunately only suspensive. ${ }^{3}$ As a consequence, clinicians have less to do with the wellknown direct complications of IBD, but there are growing preoccupations regarding established or uncertain safety concerns related to immunosuppressive treatment. IBD specialists are living in slow motion the cultural revolution brutally experienced by HIV specialists with the arrival of efficient combined antiviral treatment: these clinicians had to turn from infectious disease specialists into experts in drug management (observance, viral resistance) and drug complications (lipodystrophy, cardiovascular problems).

Immunosuppressive drugs for IBD can be deleterious through direct toxicity on organs, and promotion of serious infections or cancers. Regarding the liver, direct toxicity of anti-tumour necrosis factor (TNF) appears anecdotal ${ }^{4}$ and that of methotrexate well circumscribed and largely preventable through the experience of rheumatologists. ${ }^{5}$ Direct liver toxicity of thiopurines is more problematic, representing the most frequent cause of liver injury, together with fatty liver disease, in tertiary care IBD centres. ${ }^{6}$ Concordant data suggest that the prevalence and annual incidence of 6-mercaptopurineand azathioprine-induced hepatotoxicity

\footnotetext{
${ }^{1}$ Department of Gastroenterology, AP-HP, Hôpital Saint-Antoine F-75012 and UPMC Université Paris 06, Paris, France; ${ }^{2}$ Liver Center Munich, Department of Medicine 2, Klinikum of the LMU-Grosshadern, University of Munich, Munich, Germany

Correspondence to Professor Laurent Beaugerie, Service de Gastroentérologie et Nutrition, Hôpital Saint-Antoine 184 rue du faubourg Saint-Antoine, 75571 Paris Cedex 12, France; laurent.beaugerie@sat.aphp.fr
}

are low $\left.(3 \% \text { and } 1.4 \% \text {, respectively })^{7}\right)$, and that dose adaptation is most cases is sufficient to resolve the problem. ${ }^{6} 8$ However, a safety signal of thiopurineinduced injury of endothelial cells, essentially nodular regenerative hyperplasia, came from the use of 6-thioguanine. Nodular regenerative hyperplasia was found thereafter in the French experience to constitute a non-exceptional long-term complication of treatment with thiopurines, particularly in males with previous extensive resection of the small bowel, leading in some cases to irreversible portal hypertension. ${ }^{10} 11$ Although the reality and the extent of this risk are still a matter of debate in other parts of the world, efforts have to be made in the near future to identify risk factors, clinical symptoms (splenomegaly, portal hypertension), biological surrogate markers (drop in platelet count, acquired cholestasis), non-invasive detection tools $\left(\mathrm{MRI}^{12}\right.$ transient elastography ${ }^{13}$ ) and preventive measures (correction of folate and vitamin $\mathrm{B}_{12}$ deficiency in patients with malnutrition or previous small bowel resection). ${ }^{11}$

Reactivation of hepatitis B and C under immunosuppressive treatment also represents a clinically challenging situation, even though concerning a minority of patients of IBD. The first step in addressing the problem is to identify patients at risk when initiating immunosuppressive treatment. Regarding this point, systematic hepatits B virus (HBV) vaccination and serological testing before introducing immunosuppressive treatment have been recommended in the ECCO (European Crohn's and Colitis Organisation) guidelines on opportunistic infections, whereas no consensus could be reached for hepatitis C Virus (HCV) screening. ${ }^{14}$

The prevalence of patients with IBD at risk for reactivation of hepatitis has been clarified in a prospective cross-sectional nationwide Spanish study. ${ }^{15}$ In this country, the prevalence of patients with IBD with hospital-based follow-up who had biological markers of present and/or past $\mathrm{HBV}$ or $\mathrm{HCV}$ infection was $9.7 \%$, a level similar to that of the local reference general population and lower than in previously published series. The authors also pointed out the low prevalence (12\%) of patients with IBD with effective HBV vaccination, and observed that transfusion was no longer a significant risk factor for $\mathrm{HCV}$ infection as soon as HCV markers became mandatory in blood banks.

In this issue of Gut (see page 1340), the same Spanish REPENTINA group addressed the question of the prevalence and risk factors for liver dysfunction (LD) related to hepatitis $B$ and $C$ in patients with IBD receiving immunosuppressive treatment. ${ }^{16}$ They identified from the previous study 104 patients with HBV markers (25 hepatitis B surface antigen (HBsAg) positive), 74 with HCV markers (51 HCV RNA positive) and 16 patients with markers of both infections, who have been treated at some time with immunosuppressive drugs. They retrospectively assessed in these patients the frequency and severity of LD according to exposure to one or more immunosuppressive drugs, with a median treatment time of $\sim 1$ year. The reader not familiar with the hepatology literature has first to be clear about consensual or adapted definitions of liver abnormalities in order to fully understand the results. According to an international classification based on biological tests alone, ${ }^{17}$ 'abnormalities' of liver tests can been defined as an increase in aspartate transaminase, alanine transaminase (ALT), alkaline phosphatase (AP), $\gamma$-glutamyl transferase or total bilirubin between $\mathrm{N}$ (upper limit of the normal range) and $2 \mathrm{~N}$, whereas the terms 'liver injury' or 'hepatotoxicity' are proposed if there is an increase of $>2$ in the aforementioned liver tests. For the purpose of the study of hepatitis B and C in IBD, Loras et al proposed specific definitions for characterising three kinds of LD: viral reactivation or replication, acute liver failure and fulminant liver failure. For $\mathrm{HBV}$, reactivation was defined as an increase of 1.5- to 2-fold compared with the baseline value of ALT plus an increase of $>2000 \mathrm{IU} / \mathrm{ml} \mathrm{HBV}$ DNA levels or DNA reappearance in a negative patient. $\mathrm{HCV}$ replication was defined as a significant increase in RNC-HCV or RNA reappearance in a negative patient plus an increase of 1.5- to 2-fold compared with the baseline value. LD related to immunosuppressive treatment in a HCV-infected patient was defined as a significant increase of ALT or HCV RNA virus load. Acute liver 
failure was defined as a sudden and severe impairment of liver function (bilirubin $>2 \mathrm{mg} / \mathrm{dl}$, albumin $<34 \mathrm{~g} / \mathrm{l}$ or prothrombin time $<50 \%$ ) and fulminant liver failure as severe acute failure complicated by hepatic encephalopathy.

The authors observed that 36, 24 and $0 \%$ of the $25 \mathrm{HBs}$ Ag-positive patients developed $\mathrm{LD}$, hepatic failure or fulminant liver failure, respectively. Remarkably and unfortunately, only 6 of these 25 patients had received antiviral treatment before immunosuppression. No reactivation was found in antihepaptitis $B$ core antigen ( $\mathrm{HBc}$ )positive patients lacking $\mathrm{HBsAg}$. Regarding $\mathrm{HCV}$, viral reactivation was observed in only $16 \%$ of the 51 HCV RNA-positive patients, with one hepatic failure. To be treated with $\geq 2$ immunosuppressive drugs (including steroids) was an independent predictor for $\mathrm{HBV}$ reactivation (OR 8.6). Of note, no reactivation was observed in patients receiving a monotherapy with azathioprine or infliximab together with a preventive antiviral treatment against $\mathrm{HBV}$, and all the cases of liver failure occurred in patients receiving steroids alone or in combination with azathioprine or infliximab. No significant rate of progression towards cirrhosis was observed in either HBV or HCV infection. In summary, these original data are reassuring when considering initiating immunosuppressive drugs in $\mathrm{HCV}$-infected patients. The same is true for HBV-infected patients receiving antiviral preventive treatment planned to be treated with a monotherapy by azathioprine or infliximab, but without additional steroids.

Most data on HBV under immunosuppression had been collected previously in patients receiving chemotherapy for haemotological malignancies. A great merit of the Spanish study is the presentation of novel, valuable data on the effects of immunosuppression for IBD. Interestingly, the results seem to confirm the recommendations given by hepatological associations, based mainly on HBV reactivation with chemotherapy: recent practice guidelines by the AASLD (American Association for the Study of Liver Diseases) and EASL (European Association for the Study of the Liver) and the German S3 guidelines recommend prophylactic antiviral treatment for hepatitis B carriers and agree that routine prophylaxis is not indicated for HBsAg-negative, but anti-HBc-positive patients. ${ }^{18-20}$

This Spanish cooperative study is also emblematic of a modern methodological approach for addressing safety concerns in very specific subgroups of patients. Premarketing clinical trials, postmarketing reporting and huge population-based cohorts without access to detailed individual stories are not able to provide this information. In contrast, cooperative cohorts adequately tailored for addressing pre-established questions have reasonable chances to successfully address some 'orphean' clinically relevant interrogations, and must be encouraged.

\section{Competing interests None.}

Provenance and peer review Commissioned; not externally peer reviewed.

Gut 2010;59:1310-1311.

doi:10.1136/gut.2010.217331

\section{REFERENCES}

1. Dignass A, Van Assche G, Lindsay J0, et al. The second European evidence based consensus on the diagnosis and management of Crohn's disease: current management. J Crohn's Colitis 2010;4:28-52.

2. Beaugerie L, Brousse N, Bouvier AM, et al. Lymphoproliferative disorders in patients receiving thiopurines for inflammatory bowel disease: a prospective observational cohort study. Lancet 2009;374:1617-25

3. Treton X, Bouhnik Y, Mary JY, et al. Azathioprine withdrawal in patients with Crohn's disease maintained on prolonged remission: a high risk of relapse. Clin Gastroenterol Hepatol 2009; 7:80-5.

4. Carlsen KM, Riis L, Madsen OR. Toxic hepatitis induced by infliximab in a patient with rheumatoid arthritis with no relapse after switching to etanercept. Clin Rheumatol 2009;28:1001-3.

5. Visser K, van der Heijde DM. Risk and management of liver toxicity during methotrexate treatment in rheumatoid and psoriatic arthritis: a systematic review of the literature. Clin Exp Rheumato 2009;27:1017-25
6. Gisbert JP, Luna M, Gonzalez-Lama Y, et al. Liver injury in inflammatory bowel disease: long-term follow-up study of 786 patients. Inflamm Bowel Dis 2007:13:1106-14.

7. Gisbert JP, Gonzalez-Lama Y, Mate J. Thiopurineinduced liver injury in patients with inflammatory bowel disease: a systematic review. Am J Gastroenterol 2007:102:1518-27.

8. Shaye $\mathbf{0 A}$, Yadegari M, Abreu MT, et al. Hepatotoxicity of 6-mercaptopurine (6-MP) and azathioprine (AZA) in adult IBD patients. Am J Gastroenterol 2007;102:2488-94.

9. Dubinsky MC, Vasiliauskas EA, Singh $\mathrm{H}$, et al. 6-Thioguanine can cause serious liver injury in inflammatory bowel disease patients. Gastroenterology 2003;125:298-303.

10. Vernier-Massouille G, Cosnes J, Lemann M, et al Nodular regenerative hyperplasia in patients with inflammatory bowel disease treated with azathioprine. Gut 2007;56:1404-9.

11. Seksik P, Mary JY, Beaugerie L, et al. Incidence of nodular regenerative hyperplasia in patients with inflammatory bowel disease treated with azathioprine. Inflamm Bowel Dis Published online 28 June 2010. doi:10.1002/ibd.21330.

12. Zech CJ, Seiderer J, Reinisch W, et al. Thioguanine-induced nodular regenerative hyperplasia of the liver-ROC analysis of different MR techniques. Eur Radiol 2007;17:1898-905.

13. Laharie D, Vergniol J, Bioulac-Sage P, et al Usefulness of noninvasive tests in nodular regenerative hyperplasia of the liver. Eur $J$ Gastroenterol Hepatol 2010;22:487-93.

14. Rahier JF, Ben-Horin S, Chowers Y, et al. European evidence based consensus on the prevention, diagnosis and management of opportunistic infections in IBD. J Crohn's Colitis 2009;3:47-91.

15. Loras C, Saro C, Gonzalez-Huix F, et al. Prevalence and factors related to hepatitis $B$ and $C$ in inflammatory bowel disease patients in Spain: a nationwide, multicenter study. Am J Gastroenterol 2009;104:57-63.

16. Loras C, Gisbert GP, Minguez M, et al. Liver dysfunction related to hepatitis $B$ and $C$ in patients with inflammatory bowel disease treated with immunosuppressive therapy. Gut 2010; 59:1340-6.

17. Benichou C. Criteria of drug-induced liver disorders Report of an international consensus meeting. J Hepatol 1990;11:272-6.

18. Cornberg M, Protzer U, Dollinger MM, et al. Prophylaxis, diagnosis and therapy of hepatitis B virus (HBV) infection: the German guidelines for the management of HBV infection. Z Gastroenterol 2007; 45:1281-328.

19. Lok AS, McMahon BJ. Chronic hepatitis B: update 2009. Hepatology 2009;50:661-2.

20. European Association for the Study of the Liver. EASL Clinical Practice Guidelines: management of chronic hepatitis B. J Hepatol 2009; 50:227-42. 


\section{GUT}

\section{Liver dysfunction in patients with IBD under immunosuppressive treatment: do we need to fear?}

Laurent Beaugerie and Alexander L Gerbes

Gut 2010 59: 1310-1311

doi: $10.1136 /$ gut.2010.217331

Updated information and services can be found at:

http://gut.bmj.com/content/59/10/1310.full.html

These include:

References This article cites 19 articles, 2 of which can be accessed free at: http://gut.bmj.com/content/59/10/1310.full.html\#ref-list-1

Article cited in:

http://gut.bmj.com/content/59/10/1310.full.html\#related-urls

Email alerting Receive free email alerts when new articles cite this article. Sign up in service the box at the top right corner of the online article.

Notes

To request permissions go to:

http://group.bmj.com/group/rights-licensing/permissions

To order reprints go to:

http://journals.bmj.com/cgi/reprintform

To subscribe to BMJ go to:

http://group.bmj.com/subscribe/ 